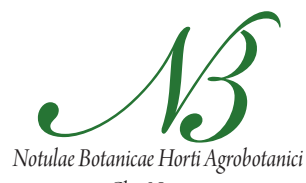

Cluj-Napoca

\title{
Response of Four Russula Species under Copper Sulphate and Lead Acetate Treatments
}

\author{
Gabriela BUSUIOC, Carmen C. ELEKES* \\ University "Valahia" of Târgovişte, Department of Environmental Engineering, Bd. Regele Carol I, \\ no. 2, Targoviste, Romania; cristina_elekesh@yahoo.com (*correspondingauthor)
}

\begin{abstract}
Mushrooms have a species-specific affinity for heavy metals in soil. Therefore, mushrooms may act as an effective bioaccumulator of metals, thus can be used in mycoremediation technologies to remove and recover heavy metals from soil. The response of four Russula species to copper sulfate and lead acetate treatments concerning the absorption, accumulation and translocation of $\mathrm{Fe}, \mathrm{Cu}, \mathrm{Zn}, \mathrm{Mn}$ and $\mathrm{Pb}$ was studied. Differences in metal concentrations were recorded between caps and stipes of the fruiting body and varied widely between the tested species. This confirms the species-dependent features of heavy metal absorption in mushrooms. Another factor that showed an influence on the bioavailability of metals in mushrooms was the metal content of soil. Similarities between the absorption and accumulation of copper and zinc were observed for $R$. vesca and $R$. atropurpurea. The treatments influenced the bioabsorption of heavy metals by the mushrooms and the metal mobility in the fruiting body. After lead acetate treatment, $R$. vesca, $R$. atropurpurea and $R$. integra had an increased bioaccumulation capacity compared to the control. Hyperaccumulating species, such as $R$. nigricans for lead soil pollution, would lead to the best results for mycoremediation as they are capable of accumulating higher concentration of heavy metals in comparison to other mushroom species.
\end{abstract}

Keywords: bioabsorption, bioavailability, heavy metals, mycoremediation

\section{Introduction}

Mushrooms (macromycetes or macrofungi) are vegetal organisms with the ability to accumulate heavy metals. This ability is explained by the presence of a rich network of hyphae which occurs in a considerable volume in the upper layer of soil. This allows mushrooms to collect required water and minerals from the soil for production of a fruiting body (Urban, 2011). The large-surface created by mycelium, which is in contact with the substrate, make mushrooms more predisposed to absorb heavy metals present in soil than the majority of other soil organisms (Mejstřik and Lepšová, 1992). Every species of mushrooms has a specific capacity, genetically controlled, for absorption of one or another heavy metal from the soil (Mejstřik and Lepšová, 1992). Heavy metal concentration in the fruiting body reflects the heavy metal content available to the mycelium in the substrate, as well as the capacity of the mycelium of each species to uptake heavy metals from the substrate (Mejstřik and Lepšová, 1992). Due to these aspects, mushrooms can be appreciated as bio-accumulators (Ahalya et al., 2003) which can be successfully utilized in mycoremediation technologies, where their features concerning the uptake of heavy metals are beneficial (Das, 2005; Amna, 2011). The capacity of mushrooms to extract heavy metals from soil was tested also by García et al. (2005) on Agaricus macrosporus which effectively extract Cd, Hg and Cu. Zabowski et al. (1990) demon- strate that fungi absorb metals after a massive sludge application. Trying to underline these aspects, Benbrahim et al. (2006) revealed that the municipal sludge application modified the heavy metal concentration in wild growing mushrooms. Other authors have studied heavy metal contents of wild growing mushrooms from heavily polluted areas and observed considerably increasing concentrations when compared with control samples (Svoboda et al., 2000). Mejstřik and Lepšová (1992) reviewed the lead and manganese concentrations in species of the genus Russula. $R$. atropurpurea was confirmed by Borovička and Ǩanda (2007) as an effective $\mathrm{Zn}$-absorbing species. To study the interactions between mushrooms and the metals from substrate, two aspects are important: the effect of metal ions on the mushrooms and the effect of fungal activity on the ions availability (Mejstřik and Lepšová, 1992).

The advantages of using mushrooms in remediation ecotechnologies include the biodiversity of mushrooms, even in space limited areas; the ubiquitousness of some species of mushrooms and the presence of mushrooms in different terrestrial habitats. The biodiversity of the genus Russula is met on all continents, and a wide number of varieties were intensively studied by many authors (Mejstřik and Lepšová, 1992; Stijve et al., 2002; Yilmaz et al., 2003). Their ubiquity, diversity and rapid metabolic activity, make mushrooms an important component of their ecosystem (Mejstřik and Lepšová, 1992). Also, the fruiting body of mushrooms have a short lifetime, generally no more that 
7-10 days, although the mycelium may live in the substratum for many years (Campos et al., 2012). Age and size of the fruiting bodies were of less importance (Das, 2005).

The concentration of heavy metals in a fruiting body is assumed to be species-dependent, but the soil concentration is also considered as an important factor (Kalač and Svoboda, 2000; Stijve et al., 2004). The uptake of heavy metals occurs as a result of physico-chemical interactions of metal ions with the cellular compounds of biological species (Kapoor and Viraraghavan, 1998). The nutritive substances are translocated to the growing fruiting bodies where they are needed for the production of spores and heavy metal ions are co-transported with the carrier system that transport nutrients (Mejstrik and Lepšová, 1992). The elements accumulate mainly in cap (particularly in gills) and less in stipe (Brunnert and Zadražil, 1980).

For the best results of the mycoremediation technologies, it is necessary to use only species (1) with hyperaccumulating abilities for metal pollutant of interest and (2) which have a positive response concerning the production and growth of fruiting bodies on the substrate with high concentration of heavy metals. The hypothesis was that the accumulation rates are correlated with the metal content of the soil and with the presence/absence of other elements in the soil (especially ions competition). The aim of this study was to identify the effect of increasing metal concentration in soil on (1) accumulation of respective metal and other elements with a biological role and (2) on the mobility of heavy metals in the fruiting body of wild growing mushrooms. Were studied the responses of four Russula species after various treatments with heavy metal solutions. This study revealed the possibility of these four Russula species to be used in mycoremediation strategies of soil polluted with heavy metals.

\section{Materials and methods}

\section{Sampling}

Lab tests for mycoremedation of heavy metal polluted soils were developed with four species of wild growing mushrooms of the genus Russula ( $R$. vesca, $R$. atropurpurea, $R$. integra, $R$. nigricans), harvested from a forestry ecosystem, in southern Romania, Dâmbovița County, between $44^{\circ} 25^{\prime}-45^{\circ} 27^{\prime} \mathrm{N}$, and $25^{\circ} 06^{\prime}-26^{\circ} 00^{\prime} \mathrm{E}$, at $240-430$ $\mathrm{m}$ altitude (Fig. 1). The studied forestry ecosystem has areas with different dominant species of trees: Durmast Oak (Quercus petraea), Oak (Quercus robur), Beech (Fagus sylvatica) and Horbeam (Carpinus betulus).

The mushrooms were sampled in last two decades of August - first decade of September 2011. The mean daily temperatures of the sampling period were between $25-30^{\circ} \mathrm{C}$ and the night temperatures were $15-20^{\circ} \mathrm{C}$. The harvested mushrooms were at either the egg or juvenile phenological phase, without sporophores or gills. The experiment was conducted on wild growing mushrooms under the hypothesis that the metal content in the fruiting body is considerably affected by the age of mycelium and by the interval between the fructifications (Das, 2005). Were formed experimental repetitions out of 2-5 exemplars, harvested with the underneath block of soil, down to $15 \mathrm{~cm}$ depth and set on $20 \times 30 \mathrm{~cm}$ plastic trays.

For one experimental repetition of a certain species of mushrooms, were harvested exemplars from a limited area of a maximum of $100 \mathrm{~m}^{2}$, because they likely grew from the same mycelium (Borovička and Randa, 2007). For each experimental variant were harvested three repetitions from different areas according to soil condition and dominant species of tree (Tab. 1).

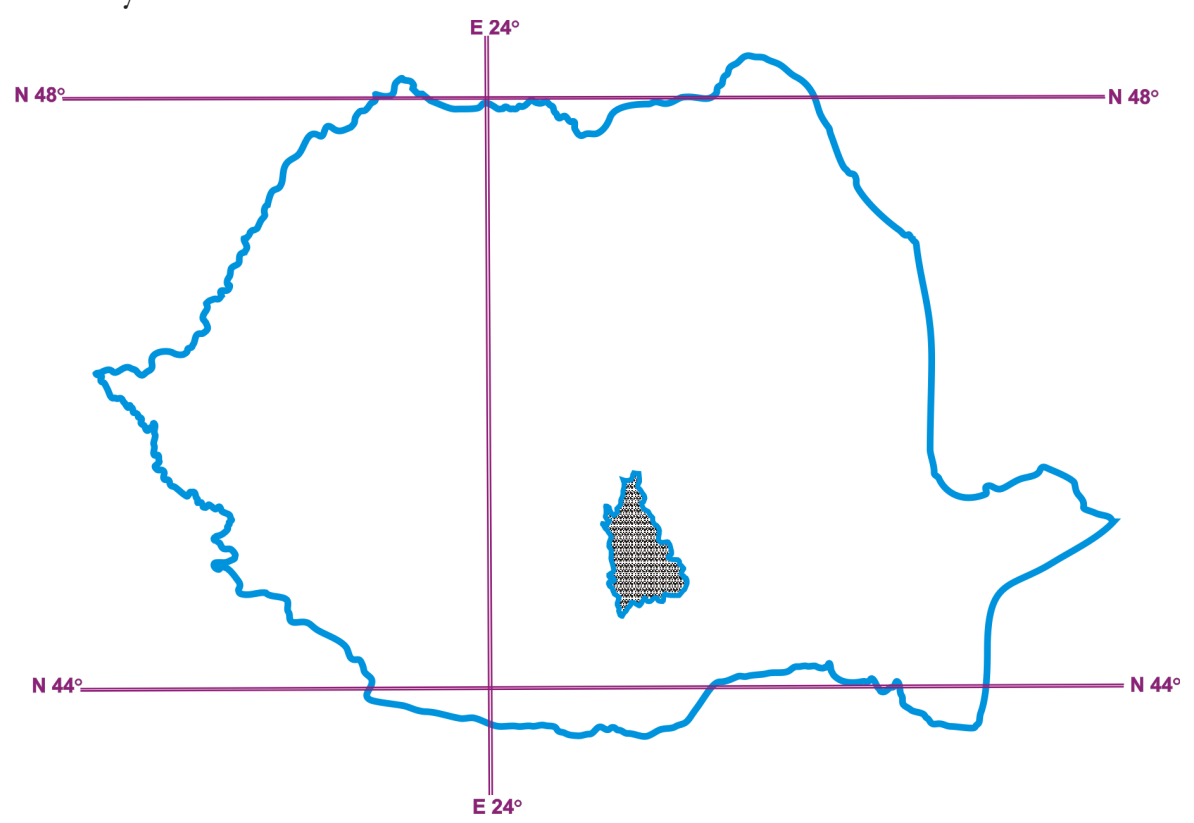

Fig. 1. Location of studied area, in South Romania, 240-430 m altitude, Oak, Durmast Oak, Beech and Hornbeam forest (Google Earth Map) 
540

Tab. 1. Experimental design and sampling area

\begin{tabular}{ccccc}
\hline Species & Control & Cu variant & Pb variant & Forest \\
\hline \multirow{3}{*}{ R. vesca } & VCR1 & VCuR1 & VPbR1 & Durmast \\
& VCR2 & VCuR2 & VPbR2 & Oak \\
& VCR3 & VCuR3 & VPbR3 & Hornbeam \\
\hline \multirow{2}{*}{ R. } & ACR1 & ACuR1 & APbR1 & Durmast \\
atropurpurea & ACR2 & ACuR2 & APbR2 & Hornbeam \\
& ACR3 & ACuR3 & APbR3 & Beech \\
\hline \multirow{3}{*}{ R. integra } & ICR1 & ICuR1 & IPbR1 & Durmast \\
& ICR2 & ICuR2 & IPbR2 & Hornbeam \\
& ICR3 & ICuR3 & IPbR3 & Oak \\
\hline \multirow{4}{*}{ R. nigricans } & NCR1 & NCuR1 & NPbR1 & Hornbeam \\
& NCR2 & NCuR2 & NPbR2 & Durmast \\
& NCR3 & NCuR3 & NPbR3 & Oak \\
\hline
\end{tabular}

$\mathrm{R}$ - repetition; Control - sprinkled with tap water; $\mathrm{Cu}$ variant - sprinkled with 6\% copper(II) sulfate $\left(\mathrm{CuSO}_{4}\right)$ solution; Pb variant - sprinkled with $1 \%$ lead(II) acetate $\left(\left(\mathrm{CH}_{3} \mathrm{COO}\right)_{2} \mathrm{~Pb}\right)$ solution

\section{Experimental design}

For each of the four mushroom species ( $R$. vesca, $R$. atropurpurea, $R$. integra and $R$. nigricans) three variants of three repetitions each were tested. The first variant was the control; the second variant was treated with $\mathrm{Cu}$ solution and the third with a Pb solution (Tab. 1). The experiment was conducted in a vegetation chamber under controlled conditions (temperature and humidity) for three to five days, dependent on mushrooms lifecycle stage. Usually, the lifetime of a fruiting body is about 7-10 days (Kalač, 2009; Campos et al., 2012). Due to the stress of displacement and chemical stress (Da Silva et al., 2012), the fruiting body does not last this long. When one or two fruiting bodies shrank, all three variants were harvested for that repeat.

During the experimental period, the temperature and relative humidity $(\mathrm{RH})$ were automatically controlled at $25^{\circ} \mathrm{C}$ and $75 \% \mathrm{RH}$ during the day; $22^{\circ} \mathrm{C}$ and $80 \% \mathrm{RH}$ during the night. To maintain the soil moisture, the soil was sprinkled daily with different solutions according to the experimental variable: (1) Control - was sprinkled with tap water; (2) Cu variant - was sprinkled with $6 \% \mathrm{w} / \mathrm{v}$ copper(II) sulfate $\left(\mathrm{CuSO}_{4}\right)$ solution; (3) $\mathrm{Pb}$ variant - was sprinkled with $1 \% \mathrm{w} / \mathrm{v}$ lead(II) acetate $\left(\left(\mathrm{CH}_{3} \mathrm{COO}\right)_{2} \mathrm{~Pb}\right)$ solution. Each tray was sprinkled with a quantity of 150 $\mathrm{ml}$ (as a total over the entire experiment) of their respective solution.

After harvesting, the fresh mushrooms were washed with deionized water to remove soil particles, dried at $60^{\circ} \mathrm{C}$ and then ground to a fine powder. The preparation and elemental analysis of mushroom samples were done separately for caps and stipes, because the heavy metal accumulation is different for the two morphological parts of the fruiting body. The underlying substrate was sampled to $10 \mathrm{~cm}$ depth (Kalač, 2010), completely dried at $40^{\circ} \mathrm{C}$ and ground to a fine powder and sieved at $250 \mu \mathrm{m}$ (according to SR ISO 11464).

\section{Analytical procedure}

The elemental content of the samples was established by Energy Dispersive X-Ray Fluorescence method (EDXRF), using ElvaX Spectrometer having an X-ray tube with an $\mathrm{Rh}$ anode operated at $50 \mathrm{kV}$ and $100 \mu \mathrm{A}$. Two grams of each sample were manually pressed, without any chemical treatment, in a plastic vial with Mylar on the bottom. The samples were excited for $300 \mathrm{~s}$, and the characteristic Xrays were detected by a multichannel spectrometer based on a solid state Si-pin-diode X-ray detector with a $140 \mu \mathrm{m}$ Be window and energy resolution of $200 \mathrm{eV}$ at $5.9 \mathrm{keV}$ (Cojocaru et al., 2006; Ene et al., 2011).

The accuracy and precision of the results were evaluated by measuring a certified reference sample NIST SRM 1571 - Orchard leaves adapted for mushroom samples and SRM 2710 - Montana soil, for substrate samples (Tab. 2). All elements which were in a concentration higher than $0.3 \mathrm{mg} / \mathrm{kg}$ were then recorded. Every result is the average of five determinations. The final results were reported to dry substances and calculated in mg of metal per kg of dry weight (mushrooms or soil) - $\mathrm{mg} / \mathrm{kg}$.

\section{Data analysis}

The heavy metal concentrations in both mushrooms and the soil underneath were expressed as means and standard deviation of the samples for each studied species. For data analysis, SPSS Statistics 17.0 software was used, to reveal the concentration differences between the control

Tab. 2. Observed and Certified values of elements in Orchard leaves $(n=5)$

\begin{tabular}{|c|c|c|c|c|c|}
\hline \multicolumn{3}{|c|}{ Element } & Certified value & EDXRF value & Recovery (\%) \\
\hline \multirow{5}{*}{$\begin{array}{l}\text { SRM } 2710 \text { - } \\
\text { Montana soil }\end{array}$} & \multirow{2}{*}{$(\%)$} & $\mathrm{Fe}$ & $3.38 \pm 0.10$ & $3.25 \pm 0.15$ & 96 \\
\hline & & $\mathrm{Mn}$ & $1.01 \pm 0.04$ & $1.11 \pm 0.08$ & 110 \\
\hline & \multirow{3}{*}{$\begin{array}{c}(\mathrm{mg} / \mathrm{kg} \\
\mathrm{DM})\end{array}$} & $\mathrm{Cu}$ & $2950.00 \pm 130.0$ & $2973.00 \pm 152.0$ & 101 \\
\hline & & $\mathrm{Zn}$ & $6952.00 \pm 91.0$ & $6895.00 \pm 138.0$ & 99 \\
\hline & & $\mathrm{Pb}$ & $5532.00 \pm 80.0$ & $5123.07 \pm 107.7$ & 93 \\
\hline \multirow{5}{*}{$\begin{array}{c}\text { NIST-SRM } \\
1571\end{array}$} & \multirow{5}{*}{$(\mathrm{mg} / \mathrm{kg})$} & $\mathrm{Fe}$ & $300.00 \pm 20.0$ & $307.22 \pm 18.3$ & 102 \\
\hline & & $\mathrm{Cu}$ & $12.00 \pm 1.0$ & $11.75 \pm 1.6$ & 98 \\
\hline & & $\mathrm{Zn}$ & $25.00 \pm 3.0$ & $23.96 \pm 2.2$ & 96 \\
\hline & & $\mathrm{Mn}$ & $91.00 \pm 4.0$ & $89.72 \pm 6.7$ & 99 \\
\hline & & $\mathrm{Pb}$ & $45.00 \pm 3.0$ & $48.15 \pm 4.2$ & 107 \\
\hline
\end{tabular}


and treated variant. The graphs represent the mean of the repetitions and the error bars represent the standard deviation. To establish the statistically significant interspecies differences in metal absorption a Paired Samples Statistics $T$-test was applied. Was tested the statistical significance, $5 \%$ significance level, to demonstrate the differences in metal absorption by the four studied species of Russula species.

\section{Results and discussion}

\section{Soil characteristics}

The moisture of the substrate of studied mushrooms ranged between $18-42 \%$. The iron concentration obtained in this experiment (Tab. 3) is similar to results obtained in a previous study (Busuioc et al., 2011) where were analysed natural soil, without any other treatments. Also, copper and zinc concentrations found in this study, were in agreement with this previous study. The copper concentration was three times higher than the normal value for an organic soil ( $1-115 \mathrm{mg} / \mathrm{kg}$ ) (Kabata-Pendias and Pendias, 1993). Zinc concentration was also found at a higher than normal value for an organic soil $(57-100 \mathrm{mg} / \mathrm{kg}$ ) (KabataPendias and Pendias, 1993). The manganese content of the soil did not exceed the threshold limit of normal values of $650 \mathrm{mg} / \mathrm{kg}$ (FOREGS, 2005). The lead concentration did not exceed the normal values of $20 \mathrm{mg} / \mathrm{kg}$ (KabataPendias and Pendias, 1993).

\section{Trace elements concentration in control samples}

The four studied Russula species have similar morphological features, but different capacity of heavy metal

Tab. 3. Values of metal concentrations in soil underneath fruiting body of mushrooms

\begin{tabular}{ccccc}
\hline & Minimum & Maximum & Mean & SD \\
\hline $\mathrm{Fe}(\mathrm{g} / \mathrm{kg}$ dry weight $)$ & 57.02 & 76.52 & 67.06 & 8.25 \\
$\mathrm{Cu}(\mathrm{mg} / \mathrm{kg}$ dry weight $)$ & 304.74 & 824.57 & 498.16 & 213.49 \\
$\mathrm{Zn}(\mathrm{mg} / \mathrm{kg}$ dry weight $)$ & 2914.73 & 5075.32 & 3887.81 & 781.38 \\
$\mathrm{Mn}(\mathrm{mg} / \mathrm{kg}$ dry weight $)$ & 341.24 & 582.14 & 480.44 & 84.02 \\
$\mathrm{~Pb}(\mathrm{mg} / \mathrm{kg}$ dry weight $)$ & 9.68 & 16.84 & 12.24 & 2.73 \\
\hline
\end{tabular}

bioabsorption (Busuioc et al., 2011). The percentage of dry matter in the studied species ranged between $9 \%$ and $22 \%$.

The mean value of metal concentration in mushrooms (Tab. 4) varied widely across the four species, with some exceptions. Iron concentration varied between 207.50 and $1985.36 \mathrm{mg} / \mathrm{kg}$ dry weight. The lowest values were in the cap of $R$. nigricans, and the highest in the stipe of $R$. atropurpurea species. Similarities of iron absorption were observed between the species $R$. vesca and $R$. atropurpurea on the one hand; and on the other hand between $R$. integra and $R$. nigricans. For all studied species, the iron concentration had higher values in stipe of the fruiting body, where is also the highest variance between species. Excessive iron accumulation in stipe of $R$. vesca and $R$. atropurpurea shows the physiological affinity of the two species to sequester this element in the lower part of the fruiting body. Comparing to this study, similar results were obtained by other authors, who studied mushrooms from unpolluted areas: $31.3-1190 \mathrm{mg} \mathrm{Fe} / \mathrm{kg}$ (Sesli and Tüzen, 1999) and 102 - $1580 \mathrm{mg} \mathrm{Fe} / \mathrm{kg}$ (Soylak et al., 2005).

Adejumo and Awosanya (2005) found in R. vesca harvested from Akoko region, an iron concentration of 1180 $\mathrm{mg} / \mathrm{kg}$ dry weight in the whole fruiting body. Another extensive study about the metal concentration in mushrooms from Czech and Slovak Republics (Borovička and Řanda, 2007) has presented iron and zinc concentration in some Russula species: $83.2-132 \mathrm{ppm}$ Fe and $110-171 \mathrm{ppm}$ $\mathrm{Zn}$ for $R$. vesca; 60.3-96.2 ppm Fe and 745-1062 ppm Zn for $R$. atropurpurea; $54.5 \mathrm{ppm} \mathrm{Fe}$ and $81.1 \mathrm{ppm} \mathrm{Zn}$ for $R$. integra; and 57.3-191 ppm Fe and 40.1-46.2 ppm $\mathrm{Zn}$ for $R$. nigricans. These concentrations are comparable to iron concentration found in this study.

Zinc concentrations found by Borovička and Řanda (2007) for $R$. vesca, $R$. integra and $R$. nigricans are in agreement with values of zinc concentration found in this work. For $R$. atropurpurea, Borovička and Řanda (2007) found a zinc concentration of 3-4 times higher, which they explained by $\mathrm{Zn}$-accumulating affinity of this species. $R$. nigricans showed the lowest value of $\mathrm{Zn}$ concentration, comparing to other three studied species, like in a previous

Tab. 4. Mean values of metal concentration in control mushrooms ( $\mathrm{mg} / \mathrm{kg}$ dry weight)

\begin{tabular}{ccccccc}
\hline Species & & $\mathrm{Fe}$ & $\mathrm{Cu}$ & $\mathrm{Zn}$ & $\mathrm{Mn}$ & $\mathrm{Pb}$ \\
\hline \multirow{2}{*}{ R. vesca } & $\mathrm{C}$ & $277.69 \pm 15.29^{\mathrm{a}}$ & $18.56 \pm 1.23^{\mathrm{a}}$ & $172.07 \pm 8.42^{\mathrm{a}}$ & $122.68 \pm 8.42^{\mathrm{a}}$ & $\mathrm{ND}$ \\
& $\mathrm{S}$ & $1935.51 \pm 20.49^{\mathrm{a}}$ & $18.24 \pm 1.07^{\mathrm{a}}$ & $125.19 \pm 12.36^{\mathrm{a}}$ & $1040.19 \pm 11.36^{\mathrm{a}}$ & $\mathrm{ND}$ \\
\hline \multirow{2}{*}{ R. atropurpurea } & $\mathrm{C}$ & $310.43 \pm 5.99^{\mathrm{a}}$ & $19.85 \pm 1.49^{\mathrm{b}}$ & $204.96 \pm 9.24^{\mathrm{a}}$ & $151.79 \pm 6.60^{\mathrm{a}}$ & $\mathrm{ND}$ \\
\hline \multirow{2}{*}{ R. integra } & $\mathrm{S}$ & $1985.36 \pm 13.11^{\mathrm{a}}$ & $18.43 \pm 0.32^{\mathrm{b}}$ & $123.84 \pm 5.65^{\mathrm{b}}$ & $1047.09 \pm 20.42^{\mathrm{b}}$ & $\mathrm{ND}$ \\
\hline \multirow{2}{*}{ R. nigricans } & $\mathrm{C}$ & $215.34 \pm 18.30^{\mathrm{a}}$ & $19.46 \pm 0.15^{\mathrm{c}}$ & $133.28 \pm 7.05^{\mathrm{a}}$ & $91.64 \pm 4.48^{\mathrm{a}}$ & $\mathrm{ND}$ \\
\hline & $\mathrm{S}$ & $408.89 \pm 20.23^{\mathrm{a}}$ & $17.68 \pm 0.17^{\mathrm{b}}$ & $96.55 \pm 1.14^{\mathrm{b}}$ & $176.73 \pm 5.66^{\mathrm{a}}$ & $\mathrm{ND}$ \\
\hline $\mathrm{C}$ & $\mathrm{C}$ & $207.50 \pm 12.69^{\mathrm{b}}$ & $5.09 \pm 0.16^{\mathrm{c}}$ & $45.66 \pm 0.40^{\mathrm{a}}$ & $82.05 \pm 0.88^{\mathrm{b}}$ & $\mathrm{ND}$ \\
\hline
\end{tabular}

C - cap; $\mathrm{S}$ - stipe; ND - not detected

Interspecies differences of metal bioabsorption were tested with Paired Samples Test, for cap and stipe separately: data with different lowercase letters in the same column are significantly different at $p<0.05$ 
542

study (Busuioc et al., 2011), when this species was compared with others three species. This aspect confirms Das' statement (2005) that metal uptake by the mushrooms is primarily species-dependent, while the role of genus or family is of lower importance.

For zinc and copper, the results of this study confirm Kalač's statement (2010) that most of the heavy metals are distributed in higher concentration in the cap than in stipe of a fruiting body. This statement is upheld by other authors: the caps usually have higher zinc level in cap than in stipes (Rudawska and Leski, 2005). The highest copper concentration, in both cap and stipe, was found in $R$. atropurpurea species. The results are in agreement with copper concentration presented by Campos et al. (2012) for $R$. delica $(36 \mu \mathrm{g} / \mathrm{g})$ and also by Yilmaz et al. (2003) for some species of the same genus $(10-83 \mathrm{mg} / \mathrm{kg})$.

The values of manganese concentration varied widely with obvious differences between stipe content which is twice higher than cap content. Maximum and minimum values of manganese concentration were recorded for the same species. The results obtained on mushrooms from Akoko (Adejumo and Awosanya, 2005) have shown that $R$. vesca species had a manganese concentration of $50 \mathrm{mg} /$ $\mathrm{kg}$, while Yilmaz et al. (2003) reported manganese concentrations of $7.6-29 \mathrm{mg} / \mathrm{kg}$ for 3 Russula species. The wide difference between the iron and manganese content of soil and theirs intense absorption in the stipe of fruiting body denote the great capacity of species for iron and manganese absorption, regardless of metal content.
Lead concentration was below the limit of detection in all species, in both caps and stipes. Previous papers have presented, generally, lead concentrations ranging between $1.0-7.2 \mathrm{mg} / \mathrm{kg}$ dry weight in Russula species (Yilmaz et al., 2003; Benbrahim et al., 2006; Cocchi et al., 2006). The lowest lead concentration was found by García et al. (2009) in $R$. cyanoxantha $(0.6 \mathrm{mg} / \mathrm{kg})$ and by Yilmaz et al. (2003) in Tricholoma auratum growing in unpolluted areas $(0.57 \mathrm{mg} / \mathrm{kg})$.

\section{The response of treated mushrooms}

\section{Treatment with $\mathrm{CuSO}_{4}$}

After treatment of mushroom species with $\mathrm{CuSO}_{4}$ (Tab. 5), the copper concentration modifies significantly for three of studied species in the way of increasing concentration comparing to control samples (Fig. 2). For $R$. vesca, $R$. atropurpurea and $R$. integra species, the $\mathrm{Cu}$ from the treatment solution and the available $\mathrm{Cu}$ from soil was accumulated with priority in the stipe of the fruiting body. Thus, the copper concentration after the treatment increases few times in caps and 40-50 times in stipe of the fruiting body. This pattern of accumulation denotes that the three species have an accumulation affinity for copper and the mobility of this metal is weak, because of the chemical form in treatment solution or because of the short period until harvesting the mushrooms.

Response of $R$. nigricans, after treatment, was totally different comparing to the other studied species. Even
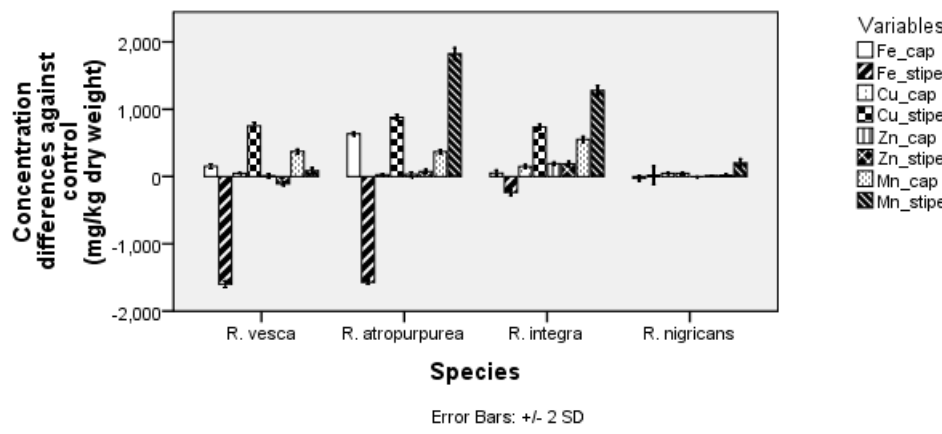

Fig. 2. Differences of metal concentration in $\mathrm{Cu}$ variant mushrooms comparing with the control

Tab. 5. Metal concentration in mushrooms after soil enrichment with $\mathrm{Cu}$ solution $(\mathrm{mg} / \mathrm{kg})$

\begin{tabular}{|c|c|c|c|c|c|c|}
\hline Species & & $\mathrm{Fe}$ & $\mathrm{Cu}$ & $\mathrm{Zn}$ & $\mathrm{Mn}$ & $\mathrm{Pb}$ \\
\hline \multirow{2}{*}{ R. vesca } & $\mathrm{C}$ & $428.47 \pm 12.99$ & $66.57 \pm 3.18$ & $181.51 \pm 8.71$ & $495.20 \pm 16.80$ & $\mathrm{ND}$ \\
\hline & S & $335.79 \pm 18.96$ & $767.54 \pm 29.57$ & $18.20 \pm 1.42$ & $1124.40 \pm 21.70$ & ND \\
\hline \multirow{2}{*}{ R. atropurpurea } & $\mathrm{C}$ & $944.12 \pm 11.62$ & $47.14 \pm 6.00$ & $235.89 \pm 19.63$ & $519.24 \pm 15.56$ & ND \\
\hline & S & $414.85 \pm 12.79$ & $897.78 \pm 23.58$ & $198.05 \pm 14.75$ & $2870.60 \pm 46.43$ & ND \\
\hline \multirow{2}{*}{ R. integra } & $\mathrm{C}$ & $266.38 \pm 16.71$ & $168.20 \pm 13.27$ & $324.19 \pm 11.90$ & $641.70 \pm 25.83$ & ND \\
\hline & S & $172.04 \pm 14.95$ & $753.87 \pm 21.28$ & $284.15 \pm 19.09$ & $1456.07 \pm 43.15$ & ND \\
\hline \multirow{2}{*}{ R. nigricans } & $\mathrm{C}$ & $184.15 \pm 18.24$ & $51.83 \pm 5.49$ & $41.46 \pm 2.52$ & $99.08 \pm 12.63$ & ND \\
\hline & S & $377.51 \pm 21.16$ & $49.11 \pm 7.72$ & $54.51 \pm 4.74$ & $357.57 \pm 33.18$ & ND \\
\hline
\end{tabular}

C - cap; $\mathrm{S}$ - stipe; ND - not detected 
if the substrate of all species was enriched with the same quantity of $\mathrm{Cu}$, the copper concentration in fruiting body of $R$. nigricans had lower values, only few times higher than the control, and copper was accumulated similarly in both cap and stipe. A possible explanation is that the metabolic mechanism of $\mathrm{Cu}$ ion exclusion was turned on by the enrichment of $\mathrm{Cu}$ in soil. This aspect indicates that $R$. nigricans species is not useful for mycoremediation technologies of copper polluted soil. This lack of an increase in metal concentration in $R$. nigricans was observed also for other metals.

For $R$. vesca, $R$. atropurpurea and $R$. integra species, a similar response was recorded after treatments concerning metal concentration in fruiting bodies. The level of iron concentration increased in cap and decreased in stipe of mushrooms. This can be explained by ion competition during absorption of copper and iron. According with the valence and atomic weight of the two metals, the copper was better absorbed and accumulated in stipe, while the absorption of iron was lagged. In presence of $\mathrm{Cu}^{2+}$, the $\mathrm{Fe}^{3+}$ ions from the soil solution were more adsorbed to soil particles and the iron bioavailability for uptake is decreasing. Also iron mobility in fruiting body increased due to a copper ions excess in stipe. $R$. vesca showed the same response for zinc, but the process had a lower intensity. For the other two species, zinc concentration showed a slight increase, similar in both cap and stipe.

Because of $\mathrm{CuSO}_{4}$ treatment, manganese solubility and bioavailability increased, showing an increase in $\mathrm{Mn}$ concentration of mushrooms, especially in stipe of $R$. atropurpurea, $R$. integra and $R$. nigricans species. The increasing of manganese concentration in mushrooms is probably explained by the synergic effect of $\mathrm{Cu}$ on the $\mathrm{Mn}$ bioavailability. Between the $\mathrm{Cu}$ and $\mathrm{Pb}$, researcher recorded an antagonistic effect (Kabata-Pendias, 2010), which was proved in this experiment too. In presence of excess $\mathrm{Cu}$ in soil, the lead bioabsorption was not modified and the concentration stayed below the detection limit for all studied species.

\section{Treatment with lead acetate}

After lead acetate treatment (Tab. 6), the lead concentration in mushrooms increased differently in studied spe- cies (Fig. 3). In $R$. vesca and $R$. atropurpurea, $\mathrm{Pb}$ concentration slightly increased compared to the control and was higher in stipe than in the cap of the fruiting body. The low quantity of absorbed $\mathrm{Pb}$ was because of exclusion mechanisms (Delian, 2008). R. integra and $R$. nigricans absorbed lead in high concentration and, probably, the carrier system transport this metal to the upper part of fruiting body where is accumulated in high concentration. The results are in agreement with previous results of Benbrahim et al. (2006), who obtained, after a liquid sludge application that contains $3.6 \mathrm{mg} / \mathrm{kg} \mathrm{Pb}$, a significant increment of $\mathrm{Pb}$ concentrations from $0.36 \mathrm{mg} / \mathrm{kg}$ in control to $1.06 \mathrm{mg} / \mathrm{kg}$ in treated plots.

Similarities of heavy metals absorption and accumulation were observed in $R$. vesca and $R$. atropurpurea for other studied elements too. The copper and zinc concentration in these species changed significantly neither in cap nor in stipe of the fruiting body. Iron and manganese showed a slight increment of concentration in caps of these two species and a significant decreasing of concentration in stipes. The decreasing of iron and manganese concentration in stipes is due to the ion competition which leads to a massive adsorption of lead ions in the "rhizosphere" (Delian, 2008). Because of the exclusion mechanism for lead, these species showed an inhibition of metal uptake and an exclusion of iron and manganese ions too.

The other two species, $R$. integra and $R$. nigricans showed a different trend of metal absorption than $R$. vesca and $R$. atropurpurea. The differences were observed only for iron and manganese, because copper and zinc concentrations did not show significant changes comparing with control samples. After the increase of lead concentration in soil, the absorption and accumulation of iron and manganese increased in both cap and stipe. Probably, lead in soil has not induced an occlusion of $\mathrm{Fe}$ and $\mathrm{Mn}$ absorption and these two species were adapted to new conditions of high level of heavy metals in soil (Delian, 2008). In areas with heavy metal pollution, the number of heavy metal resistant species increased, even if metal concentration in soil is very low (Mejstřik and Lepšová, 1992). High concentration of lead in soil can cause maximum reduction in production of fruiting body (Purkayastha and Mitra, 1992). To keep alive the fruiting body as much as possible

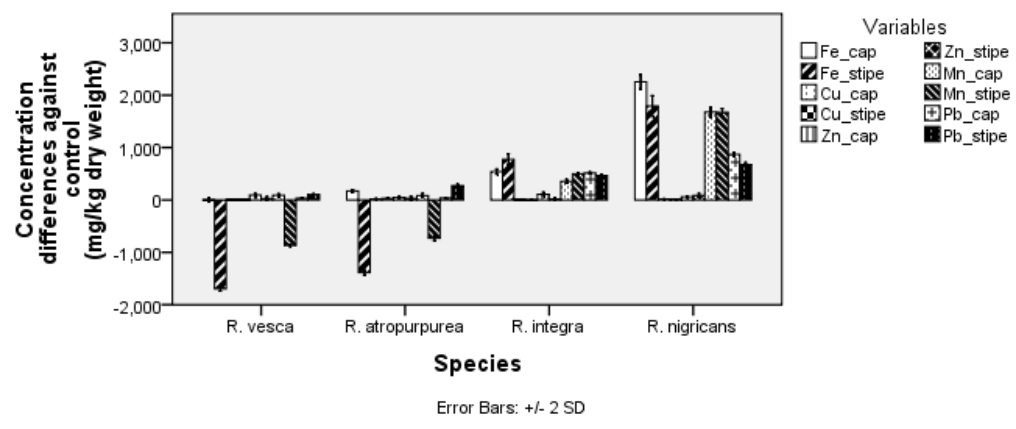

Fig. 3. Differences of metal concentration in $\mathrm{Pb}$ variant mushrooms comparing with the control 
Tab. 6. Metal concentration in mushrooms after soil enrichment with $\mathrm{Pb}$ solution $(\mathrm{mg} / \mathrm{kg})$

\begin{tabular}{ccccccc}
\hline Species & & $\mathrm{Fe}$ & $\mathrm{Cu}$ & $\mathrm{Zn}$ & $\mathrm{Mn}$ & $\mathrm{Pb}$ \\
\hline \multirow{2}{*}{ R. vesca } & $\mathrm{C}$ & $275.61 \pm 13.00$ & $25.70 \pm 2.55$ & $264.40 \pm 6.39$ & $212.55 \pm 12.12$ & $32.68 \pm 2.83$ \\
& $\mathrm{~S}$ & $239.41 \pm 16.32$ & $26.15 \pm 2.58$ & $151.83 \pm 12.88$ & $173.04 \pm 4.56$ & $102.40 \pm 6.67$ \\
\hline \multirow{2}{*}{ R. atropurpurea } & $\mathrm{C}$ & $481.89 \pm 14.39$ & $37.20 \pm 4.46$ & $247.54 \pm 8.37$ & $233.81 \pm 19.35$ & $37.10 \pm 4.37$ \\
\hline \multirow{2}{*}{ R. integra } & $\mathrm{S}$ & $597.40 \pm 23.12$ & $47.03 \pm 5.55$ & $152.49 \pm 18.95$ & $316.75 \pm 17.03$ & $271.18 \pm 16.15$ \\
\hline \multirow{2}{*}{ R. nigricans } & $\mathrm{C}$ & $754.68 \pm 21.07$ & $25.19 \pm 3.66$ & $242.23 \pm 19.18$ & $443.59 \pm 20.71$ & $512.72 \pm 10.94$ \\
\hline & $\mathrm{S}$ & $1184.61 \pm 56.25$ & $15.63 \pm 2.13$ & $112.89 \pm 11.02$ & $676.21 \pm 11.39$ & $465.88 \pm 12.35$ \\
\hline & $\mathrm{C}$ & $2460.78 \pm 75.91$ & $22.60 \pm 3.40$ & $104.18 \pm 8.90$ & $1759.09 \pm 56.17$ & $866.08 \pm 21.71$ \\
\hline
\end{tabular}

C - cap; $\mathrm{S}$ - stipe.

in stress condition, the absorption of physiologically essential heavy metals is increasing. During the absorption of essential elements the lead ions were absorbed too.

The substrate composition is an important factor of metal uptake by mushrooms. Great differences exist in uptake of individual metals (Das, 2005). The higher is the quantity of sludge application on soil, and the metal quantity by default, the higher will be the metal concentration in mushrooms. The differences in uptake of individual metals could be observed from the study of Zabowski $e t$ al. (1990) and Benbrahim et al. (2006). Zabowski et al. (1990) obtained more significant increasing of metal concentration because they used higher rates of application (27-275 Mg dry weight/ha) compared with the study of Benbrahim et al. (2006) in which only $6 \mathrm{Mg}$ dry weight/ ha was used.

\section{Conclusions}

Bioabsorption, accumulation and translocation in mushrooms are species-dependent. Each studied species showed specific responses to chemical composition of soil. The treatments with copper sulphate and lead acetate induce different responses to studied mushroom species, too. Only $R$. nigricans had an exclusion mechanism against $\mathrm{Cu}$, thus it is not recommended to be used in bioremediation technologies of soil polluted with $\mathrm{Cu}$. The increase of copper bioaccumulation in $R$. vesca, $R$. integra, and especially in $R$. atropurpurea, followed the increase of the copper content of the soil, denote the usefulness of these species for the mycoremediation technologies applied to copper polluted soils. After lead acetate treatment, $R$. vesca, $R$. atropurpurea and $R$. integra showed an increased bioaccumulation capacity in comparison to the control. The capacity of $R$. nigricans to accumulate lead in concentration, up to 5 times the lead concentration in soil, denotes that this species is useful in mycoremediation of lead polluted soils.

\section{Acknowledgements}

This work was supported by CNCSIS -UEFISCSU, project number PNII - IDEI 624/2008, coordinated by Associate Professor Gabriela BUSUIOC.

\section{References}

Adejumo TO, Awosanya OB (2005). Proximate and mineral composition of four edible mushroom species from South Western Nigeria. Afr J Bitechnol 4(10):1084-1088.

Ahalya N, Ramachandra TV, Kanamadi RD (2005). Biosorption of Heavy Metals. Res J Chem Environ 7:71-78.

Amna J (2011). Bioremediation of industrial heavy metals: Biosorption by Macromycetes, VDM Verlag Dr. Müller ISBN10:3639331346.

Benbrahim M, Denaix L, Thomas AL, Balet J, Carnus JM (2006). Metal concentrations in edible mushrooms following municipal sludge application on forest land. Environ. Pollut 144:847-854.

Borovička J, Řanda Z (2007). Distribution of iron, cobalt, zinc and selenium in macrofungi. Mycol Prog 6(4):249-259. DOI: 10.1007/s11557-007-0544-y.

Brunnert H, Zadražil TC (1980). Translocation of cadmium and mercury in straw columns colonized by the fungus Pleurotus cornucopiae Paul ex. Fr.. Eur J Appl Microbiol 10:145154.

Busuioc G, Elekes CC, Stihi C, Iordache S, Ciulei SC (2011). The bioaccumulation and translocation of $\mathrm{Fe}, \mathrm{Zn}$, and $\mathrm{Cu}$ in species of mushrooms from Russula genus. Environ Sci Pollut Res 18:890-896. DOI: 10.1007/s11356-011-0446-z.

Campos JA, De Toro JA, Pérez de los Reyes C, Amorós JA, García-Moreno R (2012). Lifestyle influence on the content of copper, zinc and rubidium in wild mushrooms. App Environ Soil Sci Hindawi Publishing Corporation, article ID 687160, 6 pages, doi: 10.1155/2012/687160.

Cocchi L, Vescovi L, Petrini LE, Petrini O (2006). Heavy metals in edible mushrooms in Italy. Food Chem 98:277-284. doi: 10.1016/j.foodchem.2005.05.068.

Cojocaru V, Pantelica A, Pincovschi E, Georgescu II (2006). EDXRF versus INAA in pollution control of soil. J Radioanal Nucl Chem 268(1):71.

Da Silva MCS, Naozuka J, da Luz JMR, de Assunção LS, Oliveira PV, Vanetti MCD, Bazzolli DMS, Kasuya MCM (2012). Enrichment of Pleurotus ostreatus mushrooms with selenium in coffee husks. Food Chem 131:558-563.

Das N (2005). Heavy metals biosorption by mushrooms. Natu- 
ral Product Radiance 4(6):454-459.

Delian E (2008). Plant physiology, in Romanian. Printech Press House, Bucharest, ISBN 978-606-521-084-4.

Ene A, Pantelică A, Freitas C, Boşneagă A (2011). EDXRF and INAA analysis of soils in the vicinity of a metallurgical plant. Rom Journ Phys 56(7-8):993-1000.

FOREGS (2005). Geochemical Baseline Mapping Programme, Geochemical Atlas of Europe. ISBN 951-690-913-2. http:// www.gsf.fi/publ/foregsatlas/.

García M, Alonso J, Melgar M (2005). Agaricus macrosporus as a potential bioremediation agent for substrates contaminated with heavy metals. J Chem Technol Biotechnol 80:325-330. doi: $10.1002 /$ jctb.1203.

García MÁ, Alonso J, Melgar MJ (2009). Lead in edible mushrooms. Levels and bioaccumulation factors. J Hazard Mater 167(1-3):777-783. doi: 10.1016/j.jhazmat.2009. 01.058.

Kabata-Pendias A (2010). Trace elements in soils and plants, fourth edition, CRC Press, Taylor and Francis Group, Boca Raton, U.S.A.

Kabata-Pendias A, Pendias H (1993). Biogeochemistry of trace elements. Warszaw: PWN.

Kalač P (2009). Chemical composition and nutritional value of European species of wild growing mushrooms: A review. Food Chem 113:9-16.

Kalač P (2010). Trace element contents in European species of wild growing edible mushrooms: A review for the period 2000-2009. Food Chem 122:2-15.

Kalač P, Svoboda L (2000). A review of trace element concentrations in edible mushrooms. Food Chem 69:273-281.

Kapoor A, Viraraghavan T (1998). Biosorption of heavy metals on Aspergillus niger: Effect of pretreatment. Biores Technol 63:109.

Mejstřik V, Lepšová A (1992). Applicability of Fungi to the Monitoring of Environmental Pollution by Heavy Metals,
365-377 p. In: Market B (Ed.). Plants as biomonitors, VCH Weinheim, Germany.

Purkayastha RP, Mitra AK (1992). Metal uptake by mycelia during submerged growth and by sporocarps of an edible fungus Volvariella volvacea. Indian J Exp Biol 30:1184-1187.

Rudawska M, Leski T (2005). Macro- and microelement contents in fruiting bodies of wild mushrooms from the Notecka forest in west-central Poland. Food Chem 92:499-506.

Sesli E, Tüzen M (1999). Levels of trace elements in the fruiting bodies of macrofungi growing in the East Black Sea region of Turkey. Food Chem 65:453-460.

Soylak M, Saraçoğlu S, Tüzen M, Mendil D (2005). Determination of trace metals in mushroom sample from Kayseri, Turkey. Food Chem 92:649-652.

Stijve T, Andrey D, Lucchini GF, Goessler W (2002). Lanthanides and Others Less Common Metals in Mushrooms, Deutsche Lebensmittel-Rundschau 98, Jahrgang Heft 3.

Stijve T, Goessler W, Dupuy G (2004). Influence of soil particles on concentration of aluminium, iron, calcium and other metals in mushrooms. Deutsche Lebensmittel-Rundschau 100, Jahrgang Heft 1.

Svoboda L, Zimmermannova K, Kalač P (2000). Concentrations of mercury, cadmium, lead and copper in fruiting bodies of edible mushrooms in an emission area of a copper smelter and a mercury smelter. Sci Total Environ 246:61-67.

Urban A (2011). Metal elements and the diversity and function of ectomycorrhizal communities, diversity and biotechnology of Ectomycorrhizae. Soil Biology 25(3):231-254. DOI: 10.1007/978-3-642-15196-5_11.

Yilmaz F, Isiloglu M, Merdivan M (2003). Heavy Metals in Some Macrofungi. Turk J Bot 27:45-56.

Zabowski D, Zasoski RJ, Littke W, Ammirati J (1990). Metal content of fungal sporocarps from urban, rural and sludgetreated sites. J Environ Qual 19(3):372-377. 